\section{Unilateral Duplication of Parotid Duct. A Rare Anatomical Variation}

\title{
Abstract
}

Background: The paired parotid glands are the largest of the major salivary glands and produces mainly serous secretions. The secretion of this gland reaches the oral cavity through single parotid duct (Stensen's duct). The parotid duct begins at the anterior border of the gland, crosses the masseter muscle, and then pierces the buccinator muscle to reach the mucosa lining the mouth at the level of the cheek. The purpose of this study is to determine the morphologic features of the parotid duct and describe an anatomical variation until now unreported.

Methods and Findings: A total of 17 cadavers were used for this study in the Morphology Laboratory at the University of Pamplona. In a cadaver were findings: The main parotid duct originated two conducts: Left superior parotid duct and Left inferior parotid duct, is observed the criss-cross of the ducts, and then perforated the buccinator muscle and entered the oral cavity at a double parotid papilla containing a double opening, separated from each other in $0.98 \mathrm{~mm}$. In the remaining 33 parotid regions (97.06\%) the parotid duct is conformed to the classical descriptions given in anatomical textbooks.

Conclusions: The parotid duct anatomy is important for duct endoscopy, lithotripsy, sialography and trans-ductal facial nerve stimulation in the early stage of facial palsy in some cases. The anatomical variation also has clinical importance for parotid gland surgery and facial cosmetic surgery. To keep in mind the parotid duct variation will reduce iatrogenic injury risks and improve diagnosis of parotid duct injury.

\section{Keywords}

Parotid Gland; Double Parotid Duct; Anatomical Variation; Stensen'S Duct.

\section{Humberto \\ Ferreira-Arquez ${ }^{1}$
1 Professor Human Morphology, Medicine Program, University of Pamplona. Morphology Laboratory Coordinator, University of Pamplona.

\section{Contact information:}

\section{Humberto Ferreira-Arquez.}

Address: University Campus. Kilometer 1, Via Bucaramanga. Pamplona. Norte de Santander, Colombia, Suramérica.

Zip code: 543050.

Tel: 75685667.

Fax: 75682750.

झ humfear@unipamplona.edu.co 


\section{Introduction}

The paired parotid glands are the largest of the major salivary glands in humans and weigh, on average, $15-30 \mathrm{~g}$. Located in the preauricular region and along the posterior surface of the mandible, each parotid gland is divided by the facial nerve into a superficial lobe and a deep lobe. The superficial lobe, overlying the lateral surface of the masseter muscle, is defined as the part of the gland lateral to the facial nerve. The deep lobe is medial to the facial nerve and located between the mastoid process of the temporal bone and the ramus of the mandible [1]. The parotid gland is bounded superiorly by the zygomatic arch. Inferiorly, the tail of the parotid gland extends down and abuts the anteromedial margin of the sternocleidomastoideus muscle. This tail of the parotid gland extends posteriorly over the superior border of the sternocleidomastoideus muscle toward the mastoid tip. The deep lobe of the parotid gland lies within the parapharyngeal space. [2] An accessory parotid gland may also be present lying anteriorly over the masseter muscle between the parotid duct and zygoma. Its ducts empty directly into the parotid duct through one tributary. Accessory glandular tissue is histologically distinct from parotid tissue in that it may contain mucinous acinar cells in addition to the serous acinar cells. [3]

The retromandibular vein, formed by the union of the maxillary vein and the superficial temporal vein, runs through the parotid gland just deep to the facial nerve to join the external jugular vein. There is substantial variation in the surgical anatomy of the retromandibular vein, which may bifurcate into an anterior and posterior branch. The anterior branch can unite with the posterior facial vein, forming the common facial vein. The posterior facial vein lies immediately deep to the marginal mandibular branch of the facial nerve and is therefore often used as a landmark for identification of the nerve branch, especially at the antegonial notch of the mandible where the nerve dips inferiorly. The posterior branch of the retromandibular vein may combine with the postauricular vein above the sternocleidomastoideus muscle and drain into the external jugular vein. During superficial parotidectomy and open reduction of mandibular condylar fractures, the retromandibular vein is used as a guide to expose the facial nerve branches [4-6]. The facial nerve exits the skull base via the stylomastoid foramen, before entering the posterior portion of the parotid gland, motor branch are given off to innervate the posterior belly of the digastricus muscle, the stylohyoideus muscle, the auricularis posterior and auricularis superior muscle, the venter occipitalis of the occcipitofrontalis muscle. The main trunk of the facial nerve then passes through the parotid gland and divides into the temporofacial and lower cervicofacial divisions approximately $1.3 \mathrm{~cm}$ from the stylomastoid foramen [1].

The parotid gland is an irregular lobulated, yellowish mass and produces mainly serous secretions. The secretion of this gland reaches the vestibule of the oral cavity through single parotid duct also known as Stensen's duct (by Danish neuroanatomist Neils Stensen), is about $5 \mathrm{~cm}$ long. It is formed near the center of the posterior border of the mandibular ramus by the confluence of two ducts which ascend and descend at right angles to the main duct. Only one duct is normally found in the cheek. This duct emerges horizontally from the anterior edge of the gland, it travels parallel to the zygoma, approximately $1 \mathrm{~cm}$ below it, in an anterior direction across the masseter muscle. At the anterior border of the masseter muscle, the duct turns medially, pierces the buccinator muscle, and enters the oral cavity opposite the second upper molar tooth. The lumen of the parotid duct is about 3 to $4 \mathrm{~mm}$ in diameter. Its lumen at the orifice on the oral surface of the cheek is greatly reduced in size. $[1,8]$ The purpose of this study was to determine the morphologic features of the parotid duct and describe an anatomical variation until now unreported. 


\section{Methods}

This work was previously approved by the Ethics Committee in Research and Environmental Impact of the University of Pamplona, conformed by resolution 030 of January 16 of 2014 and Resolution No. 008430 of 1993 of October 4 of the Ministry of Health of Republic of Colombia by which regulates the scientific, technical and administrative norms for health research. This descriptive crossover study was designed to determine the morphologic features and anatomical variations of the parotid duct. The region of 34 cheeks were studied serially during the years 2013-2016 in 15 male and 2 females $(n=34)$, embalmed adults cadavers in the laboratory of Morphology of the University of Pamplona. The cadavers had no trace of scars, adhesions or signs of trauma or operation. This study was carried out by routine dissection classes for undergraduate medical student's. Measurements were taken with assistance of a sliding Vernier caliper with an accuracy of $0.01 \mathrm{~mm}$ during the course of the anatomical dissection. The data thus obtained were recorded in a physical matrix and were consigned in digital media using Excel tables. Topographic details of the variations were examined, recorded and photographed.

\section{Results}

The anatomical variations described were found during routine dissection in one male cadaver of 47 years $(2.94 \%)$. The parotid region containing the duct was carefully dissected and the neighboring anatomic structures were taken. The anatomical findings were:

From the anterior edge of the parotid gland emerged a single duct (the main parotid duct-MPD) had a straight course and ran horizontally, the MPD has a length of $10 \mathrm{~mm}$ and a diameter of the $6.54 \mathrm{~mm}$ (Figure $1 \&$ Table 2).

The MPD originated two conducts: Left superior parotid duct (LSPD) and Left inferior parotid duct



Table 1. Measurement of the double parotid duct on the left side.

\begin{tabular}{|l|c|c|}
\hline & $\begin{array}{c}\text { Upper duct } \\
\text { left }\end{array}$ & $\begin{array}{c}\text { Lower duct } \\
\text { left }\end{array}$ \\
\hline mm & $\mathrm{mm}$ \\
\hline Length & 49.8 & 52.9 \\
\hline Diameter & 5.53 & 5.95 \\
\hline $\begin{array}{l}\text { Distance between tragus } \\
\text { and emergence point }\end{array}$ & 52.9 & 52.85 \\
\hline $\begin{array}{l}\text { Distance between } \\
\text { zygomatic arch and duct }\end{array}$ & 20 & 30 \\
\hline
\end{tabular}

Table 2. Measurement of the main parotid duct on the left side.

\begin{tabular}{|l|c|}
\hline & Left \\
\cline { 2 - 2 } & $\mathrm{mm}$ \\
\hline Length & 10 \\
\hline Diameter & 6.54 \\
\hline Distance between tragus and emergence point & 43 \\
\hline Distance between zygomatic arch and duct. & 24.97 \\
\hline
\end{tabular}

(LIPD), the two ducts ran horizontally and crossed the masseter muscle (the distance between the LSPD and LIPD was $16.7 \mathrm{~mm}$ ), curved its anterior edge and turns medially, the ducts remain separated. To $20.5 \mathrm{~mm}$ of the anterior border of masseter 
muscle is observed the criss-cross of the ducts, and then perforated the buccinator muscle and entered the oral cavity at a double parotid papilla containing a double opening, separated from each other in $0.98 \mathrm{~mm}$ (Figure 1). The LSPD open the mouth upon a small papilla opposite the second upper molar Crown. The LIPD open the mouth upon a small papilla opposite the first upper molar Crown. The Table 1 sumarize lengths and diameters of the ducts.

In the remaining 33 parotid regions (97.06\%) the parotid duct is conformed to the classical descriptions given in anatomical textbooks:

The mean length of parotid duct was $48.6 \pm 1.35$ $\mathrm{mm}$, and the mean diameter was $2.87 \pm 1.07$.

Accessory salivary tissue was identified in 12 of the 17 cadavers examined (70\%) located in the middle of the cheek. The accessory gland was bound to the masseter muscle by an extension of the masseteric fascia. It was found in close relation to Stensen's duct in the anterior course of the duct across the muscle, usually lying on or above the duct. The average size was $15.8 \pm 1.02 \mathrm{~mm}$. These were bilateral in 5 (42\%), right-sided in 4 (33\%) and left-sided in 3 (25\%).

The average distance of distinctly separated accessory glands from the anterior edge of the main gland was $5.87 \mathrm{~mm}$.

There was no evidence of accessory duct of the parotid gland

\section{Discussions}

The embryonic development of the parotid gland (PG) is well established. It arises from the epithelial lining the primitive oral cavity and can be recognized in human embryos about $8 \mathrm{~mm}$ long, at the sixth week of gestational age. Its development begins as an elongated furrow running dorsally from the angle of the mouth, between the mandibular and maxillary prominences. The groove then converts into a tube, loses its connection with the epithelium of the mouth except at its ventral end, grows dorsally, and invaginates into the adjacent mesenchyme in the cheek region. The tube persists as Parotid duct (PD) and its blinded end sprouts to several epithelial branches that proliferate to form the secretory portion (acini) of the gland at the tenth week of gestation. The secretory function of this gland starts around the 18th gestational week. Subsequently, the size of oral fissure is reduced by partial fusion between the maxillary and mandibular prominences and the duct opens thereafter, on the inside of the cheek at some distance from the angle of the mouth [8-10].

The presence of double parotid ducts can be explained on the basis of developmental morphology of the parotid gland. Avery et al. described development of the parotid gland in six stages: induction of bud formation from the oral epithelium by the underlying mesenchyme; formation and growth of epithelial cord; initiation of branching in terminal parts of the cord; lobule formation through repetitive branching of the epithelial cord; canalization of the cords to form ducts; and cytodifferentiation. The growth, cytodifferentiation and morphogenesis of the parotid gland depend on both intrinsic and extrinsic factors. The programmed pattern of cell-specific gene expression is the genetic script established early in development, while extrinsic factors include cell-cell and cell-matrix interactions and growth factors. An intact basal lamina and the presence of mesenchyme are required for normal branching [11]. The synthesis and deposition of both types I and III collagen appear to be required for parotid gland branching morphogenesis [12]. Type IV collagen and, to a limited extent, laminin have been shown to play a role in the regulation of the differentiation of parotid gland secretory cells and to some extent ductal cells. Collagen synthesis stabilizes and maintains the branch points. Specific growth factors presented by extracellular molecular proteins appear to regulate events such as branching and lobule elongation [11]. 
The cell-matrix interactions and growth factors are increasingly important to the understanding of how the developmental signals are transmitted or mediated by extracellular matrix molecules of the basement membrane and associated mesenchyme regulate specific gene expression and cellular function leading to morphogenesis and cytodifferentiation of parotid gland and development of such variant [13].

The parotid gland is located below the external acoustic meatus and zygomatic arch and between the ramus of mandible and sternocleidomastoid muscle. Most benign neoplasms are found within the superficial lobe and can be removed by a superficial parotidectomy. Tumors arising in the deep lobe of the parotid gland can grow and extend laterally, displacing the overlying superficial lobe without direct involvement. These parapharyngeal tumors can grow into "dumbbell-shaped" tumors, because their growth is directed through the stylomandibular tunnel [14]. Sternocleidomastoideus can be used in several ways by the surgeons who harvest these muscle flaps for reconstructions such as during parotid surgery (parotidectomy), where the Sternocleidomastoideus muscle could serve as an excellent candidate for myocutaneous flap, may cover the surgical defects and possibly preventing Frey's sindrome $[15,16]$

Aktan et al reported a case of double PD in the right side of the face of a 63-year-old male cadaver that merged with each other at a distance of $7 \mathrm{~mm}$ before perforating the buccinator muscle. They stated that these ducts were intra- parotid ascending and descending ducts, which did not merge inside the PG as it occurs normally [7]. An unilateral double parotid duct with the superior duct measuring 28 $\mathrm{mm}$ and the inferior duct measuring $37 \mathrm{~mm}$ merged to form the main parotid duct within an accessory parotid gland and then emerged to run forward to pierce the buccinator; the length of the main parotid duct was $25 \mathrm{~mm}$ [10]. Double parotid ducts were seen bilaterally in a 50 year old male cadaver. The length of the ducts on the right side was $29 \mathrm{~mm}$ and $36 \mathrm{~mm}$ and that of the ducts on the left side was 28 $\mathrm{mm}$ and $34 \mathrm{~mm}$. The ducts merged with each other at the level of the anterior border of masseter on both sides [13]. Peterson et al. suggested that secretion of saliva from PG that performed by Stensen's duct may be helped by possibly existing accessory PDs [17]. Double parotid ducts measuring $26.49 \mathrm{~mm}$ and $37.25 \mathrm{~mm}$ in length and merging $3.35 \mathrm{~mm}$ proximal to the piercing of buccinator were present on the right side of a 46 year old male cadaver [18]. The proper and precise knowledge of the normal topographic anatomy, dimensions of the excretory ducts and its variations are very important to those involved in their diagnosis and treatment. This variation also has clinical importance for parotid gland surgery and facial cosmetic surgeries. Clinicians for clinical procedures carrying out on this organ such as; reporting radiographic images (sialograms) and CT-scan (computerized tomographic scans), used in sialography and also for endoscopy of parotid duct, lithotripsy, and trans-ductal facial nerve stimulation in early stage of facial paralysis. Hence, the reported case can be interesting for radiologists due to analysis of radiographic images, and surgeons for performing surgical procedures on this region [10]. Double parotid ducts may be a confused with congenital fistula from accessory parotid gland. Additionally, the duct may be severed by a facial laceration and is at risk of iatrogenic injury during facial surgery and injection of botulinum toxin into masseter muscle, because of its superficial location. To keep in mind the double parotid duct variation will reduce iatrogenic injury risks and improve diagnosis of parotid duct injury [19].

Accessory parotid gland is the normal salivary tissue separated from the main parotid gland. It is located approximately $6 \mathrm{~mm}$ anterior to the parotid gland proper, between the skin and the masseter muscle, along an imaginary line that extends from the tragus to a point midway between the ala of the nose and the vermilion border of the lip [20]. 
Masses arising in the accessory parotid tissue usually occur around the central third of a line drawn from the tragus to the bottom of the ala of the nose, parallel to the main parotid duct [21]. This line lies approximately 1 fingerbreadth below the malar arch and also along the course of the buccal branch of the facial nerve [21]. The accessory parotid gland, which is little known and seldom mentioned in the literature, exists in $21 \%$ of individuals [22]. There is no known histologic difference between the accessory tissue and the parotid gland proper [23]. It is estimated that $50 \%$ of accessory parotid gland tumors are malignant, which is more than the $25 \%$ malignancy rate reported for tumors of the parotid gland proper $[24,25]$. Tumors of the accessory lobe of the parotid gland are rare and are often approached by direct incision over the mass, inadequately [26]. The behavior of these tumors is comparable to that of tumors arising from the main parotid gland. Both benign and malignant processes may arise in this area from skin, lymphatic, adnexal, neurologic, and salivary structures [20-27]. Accessory parotid gland neoplasms should be suspected in any patient presenting with a midcheek mass [28]. The accessory parotid tissue consists of a 0.5 to $2.5 \mathrm{~cm}$ lobule of serous salivary gland tissue located anterior to the main body of the gland and is attached to a short aberrant branch of the parotid gland [29]. The evaluation of a midcheek mass can be extremely challenging, and lesions from this area may arise from normal anatomic anterior facial structures or from variations of the normal accessory parotid gland tissue [21]. These glands typically lie between the buccal and zygomatic branches of the facial nerve and may have multiple connections by way of 1 or more small tributaries to the Stensen duct [28]. The differential diagnoses include benign and malignant tumors of the accessory parotid gland, parotid gland cysts, adnexal tumors, neural tumors, metastatic disease, Kimura disease, and vascular lesions such as hemangioma and vascular malformations [26, 29-31].
The morphological characteristics and the sizes of the ducts reported in the present study are divergent with the cases reported in the literature. The case presented in the present study is considered it as a rare variation has not been previously described. It is the first case reported so far in the available scientific literature.

\section{Conclusion}

The anatomical variation of the parotid duct has been reported as a rare occurrence with only a handful of literature report. These variations though rare, are likely to encounter during surgical procedures on parotid gland, routine dissection classes and at autopsy. A thorough anatomical knowledge of these variations is very useful for oral and maxillofacial surgeons, Plastic surgeons, otolaryngologists and Radiologists. A sound knowledge of these rare anatomical variations besides helping us in solving many clinical problems like formation of iatrogenic parotid fistulas may also help us in their effective surgical management and radiological diagnoses.

\section{Acknowledgements}

The author thanked to the University of Pamplona for research support and/or financial support; at National Institute of Legal Medicine and Forensics Sciences and Erasmo Meoz University Hospital in Cúcuta, North of Santander, Colombia for the donation of cadavers identified, unclaimed by any family, or persons responsible for their care, process subject to compliance with the legal regulations in the Republic of Colombia.

Research Support and/or Financial support University of Pamplona is the responsible institution

\section{Competing interests}

None 


\section{References}

1. Holsinger FC, Bui DT. Anatomy, function, and evaluation of the salivary glands. Salivary gland disorders. 2007: 1-16. Available from: https://link.springer.com/chapter/10.1007\% 2F978-3-540-47072-4_1

2. Grant J. An Atlas of Anatomy. Sixth edn. Baltimore: Williams \& Wilkins; 1972

3. Frommer J. The human accessory parotid gland: its incidence, nature, and significance. Oral Surg Oral Med Oral Pathol. 1977; 43: 671-6. Available from: http://www.sciencedirect.com/ science/article/pii/0030422077900494

4. Bhattacharyya N, Varvares M. Anomalous relationship of the facial nerve and the retromandibular vein: a case report. J Oral Maxillofac Surg. 1999; 57:75-6. Available from: http://www. joms.org/article/S0278-2391(99)90639-0/pdf

5. Ferreira- Arquez, H. Unusual venous drainage of the head and neck. Int J Pharm Bio Sci. 2014 Oct; 5(4): (B) 965 - 70. Available from: http://www.ijpbs.net/cms/php/upload/3710 pdf.pdf

6. Ferreira-Arquez $\mathrm{H}$. Variaciones anatómicas en el drenaje venoso del cuello. Rev CES Med. 2016; 30(2): 238-43. Available from: http://revistas.ces.edu.co/index.php/medicina/article/ view/3187/2685.

7. Aktan ZA, Bilge O, Atamaz Pinar Y, Omer lkiz A. Duplication of the parotid duct a previously unreported anomaly. Surg Radiol Anat. 2001; 23(5):353-4. Available from: https://link.springer. com/article/10.1007/s00276-001-0353-y

8. Williams PL, Warwick R, Dyson M, Bannister LH. Gray's Anatomy. 39th edn. London: Churchill Livingstone; 2005.

9. Moore KL, Persaud TVN. The developing human: clinically oriented embryology. 7th edn. Philadelphia: Saunders; 2002.

10. Hassanzadeh Taheri MM et al. Unilateral duplication of the parotid duct, its embryological basisand clinical significance: a rare cadaveric case report. Anat Sci Int. 2015; 90:197-200. Available from: http://en.hebut.findplus.cn/?h=articles\&db=aph \&an $=102748566$

11. Avery JK, Steele PF, Avery N. Oral Development and Histology. 3rd Ed. New York: Thieme; 2002.

12. Spooner BS, Faubion JM. Collagen involvement in branching morphogenesis of embryonic lung and salivary gland. Dev Biol. 1980; 77: 84-102. Available from: http://www.sciencedirect. com/science/article/pii/0012160680904583

13. Astik RB, Dave UH. Embryological basis of bilateral double parotid ducts: a rare anatomic variation. IJAV.2011; 4:141-3. Available from: https://www.pulsus.com/scholarly-articles/ embryological-basis-of-bilateral-double-parotid-ducts-a-rareanatomical-variation.html
14. Davis RA, Anson BJ, Budinger JM, et al. Surgical anatomy of the facial nerve and parotid gland based upon a study of 350 cervicofacial halves. Surg Gynecol Obstet. 1956; 102:385-412. Available from: https://www.scienceopen.com/ document?vid=46e54d70-de26-4174-b962-00898bfb96e4.

15. Arias DK, Ferreira H. Bilateral supernumerary sternocleidomastoid heads with clinical and surgical implications. Journal of Chemical and Pharmaceutical Research. 2016; 8 (5):52737. Available from: http://www.jocpr.com/articles/bilateralsupernumerarysternocleidomastoid-heads-with-clinical-andsurgicalimplications.pdf

16. Ferreira-Arquez $H$. Muscular variation in the neck region with narrowing of the minor and major supraclavicular fossa. International Archives Of Medicine, 2017; 10. DOI: https://doi. org/10.3823/2478

17. Peterson LJ, Ellis E, Hupp JR, Tucker MR. Contemporary oral and maxillofacial surgery. 4th edn. USA: Mosby; 2002.

18. Fernandes ACS, Lima RG, Rossi MA, Aguiar MC. Parotid gland with double duct: an anatomic variation description. Int J Morphol. 2009; 27(1):129-32. Available from: http://www. scielo.cl/pdf/ijmorphol/v27n1/art23.pdf

19. Üçerler, H, Aktan Ikiz ZA, Soylu F, Farajiband N, Yörük MD, Çagimni P. Bilateral double parotid ducts: a case report. Anatomy 2016; 10(3):239-41. Available from: http://www.anatomy.org. tr/issue/201603/pdf/12.pdf

20. Lewkowicz A, Levy $Y$, Zeltser $R$, et al. Accessory parotid gland masses. Oral Surg Oral Med Oral Pathol Oral Radiol Endod 2000; 89:610-12. Available from: http://www.000ojournal.net/ article/S1079-2104(00)78545-3/pdf

21. Sun $G$, $H u$ Q, Tang $E$, et al. Diagnosis and treatment of accessory parotid-gland tumors. J Oral Maxillofac Surg 2009; 67:1520-3. Available from: http://www.joms.org/article/S02782391(09)00037-8/abstract

22. Polayes IM, Rankow RM. Cysts, masses, and tumors of the accessory parotid gland. Plast Reconstr Surg 1979; 64:1723. Available from: http://journals.Iww.com/plasreconsurg/ Citation/1979/07000/Cysts,_Masses,_and_Tumors_of_the_ Accessory_Parotid.4.aspx

23. Frommer J. The human accessory parotid gland: its incidence, nature,and significance. Oral Surg Oral Med Oral Pathol Oral Radiol Endod 1997; 43:671-6. Available from: http://www. sciencedirect.com/science/article/pii/0030422077900494

24. Batsakis JG. Pathology consultation accessory parotid gland. Ann Otol Rhinol Laryngol 1988; 97:434-5. Available from: $\underline{\text { http:// }}$ journals.sagepub.com/doi/pdf/10.1177/000348948809700420.

25. Schmutzhard J, Schwentner IM, Andrle J, et al. Resection of accessory parotid gland tumors through a peroral approach with facial nerve monitoring. J Craniofac Surg 2007; 18:1419-21. Available from: http://journals.Iww.com/jcraniofacialsurgery/ $\underline{\text { toc/2007/11000 }}$ 
26. Choi HJ, Lee YM, Kim JH, Tark MS, Lee JH. Wide excision of accessory parotid gland with anterior approach. J Craniofac Surg 2012 Jan; 23(1):165-8. doi: 10.1097/SCS.0b013e3182413f19. Available from: http://journals.Iww.com/jcraniofacialsurgery/ toc/2012/01000

27. Lin DT, Coppit GL, Burkey BB, et al. Tumors of the accessory lobe of the parotid gland: a 10-year experience. Laryngoscope 2004; 114:1652-5. Available from http://onlinelibrary.wiley.com/ doi/10.1097/00005537-200409000-00028/pdf

28. Yoshihara T, Suzuki S, Nagao K. Mucoepidermoid carcinoma arising in the accessory parotid gland. Int I Pediatr Otorhinolaryngol 1999; 48:47-52. Available from: https://www. jstage.jst.go.jp/article/jjshns/21/2/21 2 185/pdf

29. Slater LJ, Edwards RC, Faircloth WJ, et al. Lymphoepithelial lesión of accessory parotid presenting as a buccal space mass. J Oral Maxillofac Surg 1992; 50:1131-5. Available from: http://www. sciencedirect.com/science/article/pii/027823919290508W

30. Currarino G, Votteler TP. Lesions of the accessory parotid gland in children. Pediatr Radiol 2006; 36:1-7. Available from: https:// link.springer.com/article/10.1007/s00247-005-0034-9

31. Johnson FE, Spiro RH. Tumors arising in accessory parotid tissue. Am J Surg 1977; 138:576-8. Available from: http://www. sciencedirect.com/science/article/pii/0002961079904227.

Publish in International Archives of Medicine

International Archives of Medicine is an open access journal publishing articles encompassing all aspects of medical science and clinical practice. IAM is considered a megajournal with independent sections on all areas of medicine. IAM is a really international journal with authors and board members from all around the world. The journal is widely indexed and classified Q2 in category Medicine. 